\title{
Observations of Halley's Comet at the Time of its Nearest Approach to the Earth.
}

\author{
By E. E. Barnard.
}

Observations of Halley's comet when it was bright in the morning sky were very seriously interfered with by clouds and smoky skies. Though the comet was seen several times on a bright and thick, or cloudy sky, there were only two mornings on which satisfactory observations were possible before May I 8 . These were May 4 and 5. A few of the notes are given here.

May 3, $15^{\mathrm{h}}$. The comet was beautiful to the naked eye with a long tail. The tail, though not very bright, could be traced for a distance of $17^{\circ}$ or $18^{\circ}$. The head was about $2^{\text {nd }}$ magnitude. It was one magnitude brighter than $\gamma$ Pegasi, north of it.

May 4 , I $5^{\text {h }}$. The comet was a beautiful object. The tail could be traced for $16^{\circ}$ or $17^{\circ}$.

On the morning of May 15 at $2^{\mathrm{h}} 40^{\mathrm{m}}$ the tail, on a very thick sky and among clouds, was at least $50^{\circ}$ long, and was $3^{\circ}$ or $4^{\circ}$ broad. Clouds prevented any photographs.

In the printed observations that $I$ have seen so far, of the appearance of the tail on the mornings of May i 8 and 19 , there seems to have been one part of the phenomenon visible here that has not been mentioned elsewhere. I refer to a luminous appearance, below the beam of light, that extended to the southeast horizon. The conspicuous feature of the display on the $18^{\text {th }}$ was a rather broad shaft of light of nearly equal brightness throughout its width, with rather definite edges. This beam of light very much resembled a search-light. It stretched obliquely from the eastern horizon to the Milky Way in Aquila (a length from the comet's head of $107^{\circ}$ ), where it was lost. Between $2^{\text {h }}$ and $3^{\text {h }}$ a. m. it was a striking object. Near $\propto$ Andromedae its width was about $4^{\circ}$ or $5^{\circ}$ and it tapered somewhat towards the end. Between $\zeta$ and $\gamma$ Pegasi it was brighter than any portion of the Milky Way. Beyond $\varepsilon$ Pegasi it was fainter - perhaps only one-fourth as bright. The star 7 I Aquilae (Proctor's Chart) was exactly in the axis. I Aquilae was exactly on the north edge. $\zeta$ Pegasi was on the north edge and slightly immersed in the beam of light, while $\gamma$ Pegasi was about one-half a degree north of the axis. From this description, it will be seen that the object did not lie in the ecliptic, but made a considerable angle with it. This beam of light in all the accounts of Halley's comet on the mornings of the $18^{\text {th }}$ and $19^{\text {th }}$ of May seems to have been referred to as the $»$ tail $\ll$, and I have seen no mention of any other phenomenon connected with it.

Above this ray - to the north - the sky was free from any streamers or illumination of any kind. Below, to the southeast horizon, however, appeared to be a fainter diffused light with a comparatively dark space between it and the great beam, as if the beam were a brighter part only of the tail, while the main portion, which involved the ecliptic, extended to and below the horizon, and was separated from the brighter and narrower part by a rift - such as is frequently seen in comets' tails. The next morning showed this to be a real phenomenon belonging to the comet.

On the morning of May $19^{\text {th }}$, the ray of light had sensibly shifted to the north and was more tapering, and only about one half as bright as on the $18^{\text {th }}$. It was estimated to be as bright as the Milky Way. Its southern edge was quite definitely defined, while the northern side was much diffused, especially near $\gamma$ Pegasi, where it was some ten degrees wide. It could be traced to the Milky Way in Aquila (a length of $120^{\circ}$ ). I could not be sure of its extension beyond the Milky Way. It widened out very greatly near the eastern horizon, where it seemed to join a general illumination stretching along the horizon for some distance. The general brightness of the beam was estimated to be one-half that of the $18^{\text {th }}$.

At $2^{\mathrm{h}} 20^{\mathrm{m}}$ a. $\mathrm{m}$. $\%$ Aquilae and $\zeta$ Pegasi were in the axis, while $\gamma$ Pegasi was inside its southern edge (about $3^{\circ}$ within the edge) and $\alpha$ Pegasi was just inside the northern edge. The general illumination below to the southeast horizon was more definite at its upper edge. Between it and the south edge of the beam, the sky was dark. The upper edge of this broad illumination was roughly bounded by the stars $\beta$ and $\gamma$ Piscium and $\eta$ and $\zeta$ Aquarii, and it joined the beam near $\gamma$ Pegasi. This broader portion of the tail was much less bright than the great ray. The phenomena described here were seen by the other observers then present.

Unfortunately the growth of the tail could not be followed here in the morning sky as the earth approached the comet, on account of a prolonged cloudy period which, fortunately, terminated at midnight on May 17 , thus permitting the observations of May 18 and 19 . The morning of May 20 was cloudy, with rain.

Photographs were obtained on the mornings of May 4 and 5 (civil date). On May 5 the tail two and a half degrees back of the head was $34^{\prime}$ in diameter, or about 600000 miles.

As I have said, we were unable to keep a continuous watch on the phenomena of the tail in the morning sky. 
There were essentially only a few fragmentary glimpses of the comet on a very bad sky from the morning of May 5 to that of the $18^{\text {th }}$. The full explanation of the phenomena seen here on May I 8 and I 9 may, therefore, be wrongly interpreted by me. To those who were more fortunate in observing the comet on the few mornings immediately preceding the $18^{\text {th }}$ of May, the true explanation will be evident.

The photographs on the morning of May 5 show, besides the main tail, several long slender streamers. These were about $I^{\prime}$ in diameter, or about 18000 miles. I do not know how far away this broad beam of light was, but assuming a distance of 100000 miles, the tail ought to have been at least $80^{\circ}$ in diameter, instead of $5^{\circ}$ as was observed on the morning of May $r 8$. One of the streamers at the above distance would have been about $5^{\circ}$ in diameter. Whether what we saw was only a streamer is immaterial, for it would seem that it was only a brighter and narrower part of the tail, the main portion of which was farther south and involved the ecliptic, and must have extended below the southeast horizon. Observers at more southerly stations will be able to verify this statement.

If the above idea is correct, there is much more evidence that the earth probabiy passed through the tail of the comet about May i 9.

In this connection, I may be permitted to mention the peculiar atmospheric conditions that prevailed here about noon on May 19 . This is necessary because something similar was seen in Germany (A. N. 44 I 4 ) and also in various widely distant parts of this country, as shown by the material gathered by the U.S. Weather Bureau from its observers, and may have some bearing on the close approach to the earth of the tail of Halley's comet.

Material in connection with this phenomenon and with the observations of the comet at the Yerkes Observatory is being collected by Professor Frost for publication at an early date.

On May I9, at noon and for several hours afterwards, the sky presented a rather unusual appearance. A horizontal bar of brilliant prismatic colors (red above) about $25^{\circ}$ or $30^{\circ}$ long, was visible in the south at an altitude of about $20^{\circ}$. This phenomenon was produced among high cirrus clouds. The low cumulus clouds from the south obscured the band in passing. Around the sun was a prismatic halo, $22^{\circ}$ in diameter, as measured by Mr. Lee with a theodolite. All about the sun were patches of iridescence on the cirrus.

I had begun a record of the appearance of the sky on that morning. My notes show that these colors were not present at $10^{\mathrm{h}} \mathrm{O}^{\mathrm{m}}, 1 \mathrm{O}^{\mathrm{h}} 2 \mathrm{O}^{\mathrm{m}}$, and $\mathrm{II}^{\mathrm{h}} 5^{\mathrm{m}}$. At the last observation there were storm clouds in various directions. At $10^{\mathrm{h}} \mathrm{o}^{\mathrm{m}}$ storm clouds were visible in the south, with whitish hazy cirrus clouds in the clearer region around the sun, which also had faint hazy irregularities, but "nothing abnormal ". "Same at $10^{\mathrm{h}} 2 \mathrm{O}^{\mathrm{m}}$. " ${ }_{\mathrm{I}} \mathrm{I}^{\mathrm{h}} 5^{\mathrm{m}}$ sky fair about the sun, but misty clouds almost everywhere else." No other observation was made until $12^{\mathrm{h}} \mathrm{o}^{\mathrm{m}}$, when my attention was called to the prismatic band in the south, which was being observed by the various members of the staff. Whatever significance this phenomenon may have, it is evident from the above that these colors inade their appearance here very close to noon of May I9. A beautiful photograph of the sky was obtained by Mr. Slocum, which is valuable as a record of the appearance of the clouds at the time. It also shows the prismatic band.

With this paper, I send two drawings (reproduced on the table added to this number. Red.) which show the appearance of the tail of the comet on the mornings of May 18 and I9. I have not been able to secure as satisfactory a representation of the relative intensity of the light of the narrow portion of the tail on the two dates as might be desirable. It is only necessary to remember, however, that I have stated that the general brightness of this portion of the tail on the $18^{\text {th }}$ was about twice that on the second morning. Miss Mary Proctor has shown me a sketch which she made on the morning of May $19^{\text {th }}$ from the tower of the "Times" building in the city of New York. Her sketch closely resembles my drawing of the same date, especially in showing the fainter portion of the tail that extends to the southeast horizon. I have seen no other picture of this phenomenon, nor, indeed, any mention of it from elsewhere.

It is scarcely necessary to say that during the night of May 18 (which was beautifully clear here) the sky was perfectly normal in appearance. An active aurora, which is not an unusual phenomenon at this point, began about 9 o'clock and was in evidence in a more or less subdued form the remainder of the night. The mornings of May i 8 and 19 were good and clear.

After its passage between the earth and the sun, the comet became a splendid object in the west. To me it far exceeded all expectations as a spectacular display. . The tail was' very long, and bright for a large part of its length. On May 26 it could be traced by averted vision for a distance of 63 degrees; for about $25^{\circ}$ of its length it was very conspicuous. In the latter stages of its brightness, the tail was very gently curved, with the convex side towards the south. Out of a large mass of notes which I hope to print later, I have selected a few for presentation here. The records are in central standard time, which is $6^{\mathrm{h}} 0^{\mathrm{m}}$ slow of Gr. M. T.

May I 9 , afternoon and night cloudy.

May $2 \circ, 7^{\mathrm{h}} 50^{\mathrm{m}}$, the comet was fairly well seen with the naked eye. There seemed to be a faint tail. Sky poor. At $8^{\mathrm{h}} 35^{\mathrm{m}}$ the head was about one-half a degree in diameter, with possibly a faint diffusion of tail. It looked like a nebulous star, and was yellowish. The sky was examined carefully as late as $\mathrm{II}^{\mathrm{h}}$, but nothing further was seen of the tail. A nearly full moon made the sky very bright.

May $23,8^{\mathrm{h}} 40^{\mathrm{m}}$, the comet was seen in a break in the clouds; the head seemed to be brighter than the first magnitude, and looked like a nebulous star, with some faint tail.

May $24,8^{\mathrm{h}} 20^{\mathrm{m}}$, the head and nucleus were of the first magnitude. The diameter of the head was about $15^{\prime}$ or $20^{\prime}$. The tail for $5^{\circ}$ or $6^{\circ}$ was quite noticeable; farther out than this it was faint. $8^{\mathrm{h}} 3 \mathrm{O}^{\mathrm{m}}$, ten degrees from the head the tail was $2^{\circ}$ broad. The light of the head was bluish white and the tail could be traced for a distance of $25^{\circ}$. During the exposure, as seen with the 5 -inch guiding telescope, the nucleus seemed to grow in size, until by 
$9^{\mathrm{h}} 57^{\mathrm{m}}$ it was about 5 times as great in diameter as when first seen.

May $25,8^{\mathrm{h}} 55^{\mathrm{m}}$, the comet was a beautiful object. The head did not seem relatively so bright as on the previous night. For about $20^{\circ}$ the tail was pretty bright, and widened out very much. It seemed to diffuse northward in the direction of Jupiter at its end. $9^{\mathrm{h}} 35^{\mathrm{m}}$, the tail could be traced faintly for about $40^{\circ}$. Its south side was slightly brighter.

May $26,9^{\mathrm{h}} 15^{\mathrm{m}}$, the tail could be traced faintly for $63^{\circ}$. The south side was slightly the brighter. The comet was a striking and beautirul object. The nucleus was very much inferior to Regulus.

May $27,9^{\mathrm{h}} 30^{\mathrm{m}}$, the tail was slightly curved, with the convex side to the south. It could be traced for $53^{\circ}$. Near Jupiter it was faint, and about $3^{\circ}$ broad, and seemed to diffuse northwards as high as Jupiter. This peculiarity was noticeable on several nights, and I do not think it was an illusion. Of course in all the observations Jupiter was hidden, and oblique vision was used.

May $29,10^{\text {h }}$, the tail was noticeably curved, with the convex side to the south; this side was also a little the brighter and more definite. The comet was decidedly less bright than on the $27^{\text {th }}$.

June I I, the comet was last seen with the naked eye in strong moonlight.

Yerkes Observatory, Williams Bay, Wisconsin, I 9 1 о June 27.
On June 25 it could not be seen with the naked eye on a good sky (without moonlight), but was quite noticeable in the field glasses. The photographs showed a very faint tail about $3^{\circ}$ long.

One striking fact that was noticeable when the comet was bright in the evening sky, especially noticeable on and about May 26, was that it had a nucleus within a nucleus. To the naked eye, there was a bright stellar nucleus of the 2.7 magnitude ( $\Rightarrow$ to that of $\delta$ Leonis). With field glasses the nucleus was small, but of sensible diameter, and of a beautiful bluish-white color; it was surrounded by a much fainter, hazy nebulosity, which ran out to form the tail the view being rather an intensification of that with the naked eye. This naked-eye and field-glass "nucleus" was not the true nucleus. In the 5 -inch guiding telescope a small planetary nucleus of the 8 or 9 magnitude was seen in a denser nebulosity. It was very well defined and very yellow. About this date, therefore, naked eye and telescopic observations of the nucleus would refer to two entirely different things of exactly opposite colors. That which formed the nucleus to the naked eye was simply the small denser nebulosity about the real nucleus.

On a photograph on the $6^{\text {th }}$ of June the comet had discarded its tail, which was drifting away from it, and had formed a new one at a little different angle.

\title{
Messungen der Flächenhelligkeit des Halleyschen Kometen.
}

\author{
Von F. Hartmann.
}

Im Anschluß an die frïhere Mitteilung in A. N. 44I4 will ich hier noch über meine weiteren Beobachtungen des Halleyschen Kometen kurz berichten.

Da sich zwischen meiner a. a. O. erwähnten Beobachtung vom 20. Mai und der gleichzeitigen Beobachtung in Athen (A. N. 4414 und $442 \mathrm{I}$ ) ein offenbarer Widerspruch ergibt, muß ich hier nochmals darauf zurückkommen. An der Richtigkeit meiner Beobachtung, daß am Abend des 20. Mai der Kopf des Kometen zur Sonne hin gerichtet war, kann kein Zweifel bestehen. Ich habe damals sofort am Okular des umkehrenden Kometensuchers eine Skizze gezeichnet, die ich jetzt hier wiedergebe. Der helle, scharfbegrenzte Teil des sichelförmigen Kopfes war im Okular nach links, also in Wirklichkeit nach rechts, zur Sonne hin gewendet und ging in der Richtung der täglichen Bewegung voraus. Auch Herr Hofrat $W_{c i} \beta$ und Herr Dr. Rheden machten genau dieselbe Beobachtung. Wäre es vielleicht möglich, daß sich die Athener Beobachtungen auf den Abend des r 9 . Mai beziehen?
$\mathrm{Da}$ der Komet nach meiner am Abend des 20. Mai erhaltenen Beobachtung nun ein am Abendhimmel leicht sichtbares Objekt geworden war, verließ ich am 21. den Sonnwendstein, um in erster Linie eine Beobachtungsreihe über die Flächenhelligkeit des Kometen zu beginnen.

Der Beobachtung von Flächenhelligkeiten hat man bisher eigentümlicherweise - nicht nur in der Astronomie, sondern auch bei irdischen Erscheinungen - eine viel zu geringe Beachtung geschenkt. In der uns umgebenden Erscheinungsweit ist die Flächenhelligkeit neben Form und Farbe die wichtigste optische Qualität; bei allen photographischen Aufnahmen und vielen psychophysischen Vorgängen ist sie von fundamentaler Bedeutung. Während wir aber sonst alles $z \mathfrak{u}$ messen und in Zahlen auszudrücken verstehen, ist es uns beinahe unmöglich, über die Helligkeit der uns umgebenden Natur bestimmte Angaben zu machen; »hell « und "dunkel " sind eigentlich die einzigen Begriffe, die uns hier zur Verfügung stehen. $Z$ war hat die Beleuchtungstechnik auch für die Flächenhelligkeit eine Einheit festgesetzt; es ist die Helligkeit einer ebenen Fläche, von welcher I $\mathrm{qcm}$ senkrecht zu ihr ebenso hell leuchtet, wie die Hefner-Normallampe. Allein diese Einheit hat bisher noch nicht einmal einen Namen erhalten, ein Zeichen, wie wenig sie benutzt worden ist. Ich will die genannte Einheit im folgenden mit I Phos (ph) bezeichnen; der tausendste Teil davon ist ein Milliphos (mph), der millionste Teil ein Mikrophos (mkph); 